\title{
Dzieciństwo a nowoczesność: polska recepcja amerykańskich ideałów, czyli uwag kilka na marginesie książki Sylwii Kuźmy-Markowskiej Dziecko, rodzina i płeć w amerykańskich inicjatywach humanitarnych i filantropijnych w II Rzeczypospolitej, Warszawa 2018, Wydawnictwo Uniwersytetu Warszawskiego
}

\begin{abstract}
Abstrakt
Omawiana książka dotyczy prób przeniesienia do Polski amerykańskich nowoczesnych ideałów dzieciństwa oraz wzorców i norm życia rodzinnego. Interesująco przedstawia działania opiekuńczo-wychowawcze prowadzone w oparciu o zasady „nowoczesnej filantropii”, ale nie wykorzystuje wielu wartościowych opracowań polskich uczonych oraz koncepcji teoretycznych i metodologicznych.
\end{abstract}

Słowa kluczowe: dzieciństwo, „filantropia naukowa”, nowoczesność.

Childhood and Modernity: The Polish Reception of American Ideals, or a Few Remarks in the Margins of Sylwia Kuźma-Markowska's book Dziecko, rodzina i płeć w amerykańskich inicjatywach humanitarnych i filantropijnych w II Rzeczypospolitej, Warszawa 2018, Wydawnictwo Uniwersytetu Warszawskiego

\begin{abstract}
The studied monograph concerns attempts at the transfer of modern, American ideals of childhood and the paradigms and norms of family life to Poland. Protective and pedagogic activities based on the rules of "modern philanthropy" are presented in a very noteworthy way, although the author does not employ numerous valuable studies and theoretic and methodological conceptions from Polish scholars.
\end{abstract}

Keywords: childhood, "scientific philanthropy", modernity.

\footnotetext{
* Uniwersytet Łódzki, Wydział Nauk o Wychowaniu, Katedra Historii Wychowania i Pedeutologii. Artykuł otrzymano: 22.05.2020; akceptacja: 22.05.2020.
} 
Przemianom rodziny w dobie nowoczesności poświęcono w ostatnich latach wiele prac, które przyjmując różnorodność i złożoność rzeczywistości rodzinnej uwzględniają różne perspektywy i strategie badawcze. Prowadzonej w oparciu o różne paradygmaty refleksyjności podlegają również historyczne przeobrażenia modelu rodziny. Prócz opracowań uznających stałość strukturalnego charakteru rodziny powstaje szereg prac eksponujących jej przeobrażenia, zmienność struktury i funkcji, analizujących transgresje form rodzinnych. Podobnym badaniom poddawane są dzieciństwo i młodzieńczość. Współczesne badania nad przeszłością, w tym przeszłością rodziny i dzieciństwa, coraz częściej opierają się na postmodernistycznej krytyce scjentystycznej teorii poznania. Wybitni metodolodzy przekonują, że rzeczywistość historyczna jest „ontologicznie i epistemologicznie społecznie kreowana” (Pomorski 2017: 24). Celem badania historycznego jest zatem nie tyle poszukiwanie „obiektywnej prawdy” i opisanie „jak było”, co dokonanie własnej interpretacji badanego wycinka rzeczywistości historycznej (co nie oznacza negacji kategorii „prawdy”). Przesunięcie akcentów z rekonstrukcji w kierunku interpretacji nie oznacza odrzucenia kanonu warsztatu naukowego historyka - przeciwnie - zmusza do pogłębienia refleksji na temat metod, założeń i celów badań nad przeszłością, inspiruje także do przemyślenia perspektyw interdyscyplinarnych i rozszerzenia pola problemowego. Również na gruncie polskich nauk humanistycznych i społecznych w badaniach nad historycznymi przemianami rodziny oraz przeobrażeniami konceptualizacji dzieciństwa i adolescencji w ostatnich latach wyraźne są tendencje poszukiwań nowych założeń teoretycznych i metodologicznych. Poszukiwanie nowych kategorii interpretacyjnych widać także w obszarze polskiej historii wychowania. Dla pogłębienia optyki badań i sformułowania nowych propozycji teoretycznych istotną wartość ma refleksja nad założeniami, ustaleniami i aparatem pojęciowym stosowanymi przez przedstawicieli innych dyscyplin wiedzy $\mathrm{w}$ badaniach nad rodziną, dzieciństwem, adolescencją jako fenomenami osadzonymi $w$ danym miejscu i czasie.

Interesującą pracą, podejmującą taką problematykę w perspektywie historii społecznej i kulturowej, jest monografia Sylwii Kuźmy-Markowskiej, historyczki i amerykanistki z Ośrodka Studiów Amerykańskich Uniwersytetu Warszawskiego, pt. Dziecko, rodzina i płeć $w$ amerykańskich inicjatywach humanitarnych i filantropijnych w II Rzeczypospolitej, wydana w 2018 r. przez Wydawnictwo Uniwersytetu Warszawskiego. Autorka skoncentrowała się na kilku programach pomocowych prowadzonych w Polsce w okresie międzywojennym przez amerykańskie organizacje filantropijne: Amerykańską Administrację Pomocy (American Relief Administration), nazywaną także Misją Hoovera, Żydowski Komitet Rozdzielczy (Jewish Distribution Committee), zwany popularnie Jointem, Amerykański Czerwony Krzyż (American Red Cross), Związek Młodzieży Chrześcijańskiej (Young Men’s Christian Association) zwany YMCA, a w Polsce także Imką. W pracy dokonano analizy działalności wymienionych organizacji na rzecz odbudowy i modernizacji życia społecznego Polski międzywojennej, opisano okoliczności i efekty dążeń mających 
na celu zaszczepienie amerykańskich standardów, ideałów oraz norm społecznych i rodzinnych w polskim społeczeństwie. Zbadano stosowane przez Amerykanów taktyki i metody, które miały służyć demokratyzacji relacji społecznych i unowocześnieniu życia rodzinnego w Polsce.

O wartości pracy świadczy bogaty materiał źródłowy. Autorka przeprowadziła kwerendę archiwalną w archiwach w Stanach Zjednoczonych, Polsce, na Białorusi i Ukrainie. Poddała analizie dokumenty (raporty, sprawozdania, zestawienia statystyczne, broszury informacyjne, materiały propagandowe, korespondencję, materiały ikonograficzne), wytwarzane przez amerykańskie organizacje filantropijne i humanitarne, działające na terenie II Rzeczypospolitej. Sięgnięto do źródeł epistolograficznych i memuarystycznych wytworzonych przez amerykańskich działaczy i działaczki; szczególnie wartościowe są dokumenty osobiste, które pozwoliły przedstawić ich prywatne oceny odrębności mentalnościowej i warunków egzystencjalnych Polaków. Drugą grupę materiałów archiwalnych stanowią dokumenty dotyczące oceny programów amerykańskich organizacji przez stronę polską oraz zamieszkującą Polskę społeczność żydowską. Wykorzystano także zespoły archiwalne zawierające materiały dotyczące współpracy amerykańskich organizacji z polskimi władzami rządowymi i samorządowymi. Autorka sięgnęła także do drukowanych wspomnień amerykańskich działaczy organizujących i prowadzących działania filantropijne w Polsce, wychodzącej w USA prasy oraz materiałów informacyjnych publikowanych $\mathrm{w}$ postaci książek i broszur. Wykorzystała również drukowane po polsku książki i broszury informujące o amerykańskich programach, a także prasę fachową wydawaną - jak napisała - „przez działaczy społecznych w II RP” (s. 24), co jest niejasne, zważywszy, że do tej grupy czasopism zaliczyła np. „Warszawskie Czasopismo Lekarskie” (periodyk wydawany przez lekarzy - którzy prowadzili także działalność społeczną, trudno jednak eksponować ten obszar ich aktywności, nie wspominając o głównych kompetencjach, pozwalających na redagowanie profesjonalnego czasopisma). Szczegółowej analizie poddano także różnej proweniencji materiały ikonograficzne (wyniki tej analizy są bardzo interesujące).

We wstępie Autorka określiła przedmiot badań, założenia i cele pracy, szeroko wyjaśniła stosowane w pracy pojęcia, stan badań, podstawę źródłową. Przedstawiła kategorie analityczne pracy: dziecko, rodzinę i płeć kulturową, ujmowane w myśl założeń społecznego konstruktywizmu. Podkreśliła znaczenie różnic społecznych, religijnych i narodowościowych jako ważnych czynników analizy. Wyznaczone kategorie stanowią punkt odniesienia w procesie badawczym wszystkich zagadnień analizowanych w pracy.

W rozdziale pierwszym zbadano obraz międzywojennej Polski w amerykańskiej prasie, sprawozdaniach, wspomnieniach wysłanników z USA i pracowników organizacji humanitarnych. Opisano sposób postrzegania i prezentowania warunków bytowych w Polsce, norm życia społecznego, relacji rodzinnych, kondycji zdrowotnej dzieci i młodzieży. W drugim rozdziale przedstawiono akcje dożywia- 
nia dzieci przez Misję Hoovera oraz Żydowski Komitet Rozdzielczy. Prócz ukazania zasad i sposobów realizacji dokarmiania najmłodszych Autorka podjęła także próbę zestawienia amerykańskich założeń pracy humanitarnej opartej na „naukowej filantropii" z polskimi praktykami. Zanalizowała również problem związków między działaniami Amerykanów na rzecz dożywiania a zmianą/trwałością pozycji dziecka w życiu społecznym w Polsce. Rozdział trzeci poświęcono formom pomocy organizowanej przez Amerykanów wobec dzieci osieroconych. Omówiono program tzw. adopcji finansowej prowadzony przez Żydowski Komitet Rozdzielniczy oraz warunki organizowania rodzinnej opieki zastępczej. Przedstawiono opinie amerykańskich pracowników humanitarnych na temat funkcjonowania domów dla żydowskich i chrześcijańskich dzieci osieroconych. Przedmiotem analizy badawczej w rozdziale czwartym były próby upowszechniania w Polsce amerykańskiego modelu „naukowego macierzyństwa”. Opisano działania mające na celu profesjonalizację praktyk macierzyńskich, adresowane do kobiet mających małe dzieci, próby wprowadzenia amerykańskich standardów w zakresie opieki nad ciężarnymi i położnicami, postawy Amerykanów wobec instytucjonalnych form opieki nad małymi dziećmi oraz ochrony macierzyństwa, w kontekście regulacji pozwalających kobietom na podjęcie pracy zawodowej. Przedstawiono także działania edukacyjne Amerykanów wobec polskich pielęgniarek i pracownic społecznych. Ostatni, piąty rozdział dotyczy inicjatyw adresowanych do chłopców i młodych mężczyzn, podejmowanych przede wszystkim przez Polską YMCA. Propagowały one ideał „muskularnego chrześcijaństwa”, którego realizacji miały służyć gimnastyka i sport jako aktywności rozwijające tężyznę fizyczną oraz pożądane postawy moralne i społeczne. Całość wieńczy podsumowujące poruszane zagadnienia zakończenie.

Omawiana monografia jest merytorycznie bardzo dobra, szczególnie w kontekście narracji i argumentacji. Czytelnicy otrzymali wartościowe opracowanie, bogate problemowo, spójne i logiczne, które będzie miało trwałe miejsce w interdyscyplinarnych badaniach nad przemianami rodziny i dzieciństwa w Polsce w warunkach nowoczesności. Jednocześnie lektura książki skłania do sformułowania kilku uwag krytycznych. Wydaje się, że konceptualizując przedmiot dociekań, warto było szerzej wykorzystać różne intelektualne odniesienia, teoretyczne i metodologiczne. I tak Autorka sięga do koncepcji władzy Michela Foucaulta, wykorzystuje je do analizy technik i strategii stosowanych przez amerykańskie organizacje humanitarne, ale można mieć wątpliwość, czy Foucaultowskie instrumentarium badawcze zostało dostatecznie wykorzystane. Autorka kilkakrotnie odwołuje się do niego, dokonując krytycznej analizy form władzy w jej wybranych przejawach - i tak np., pisząc o architekturze gmachów YMCA, odwołuje się do „opisywanego przez Michela Foucaulta Panoptykonu, umożliwiającego nieustanny nadzór bez konieczności ciągłej fizycznej obecności kontrolującego czy też bez potrzeby użycia siły" (s. 313). Istotniejsze byłoby jednak zbadanie projektu Panoptykonu w nieco innym kontekście. Został on przez Foucaulta zapożyczony od 
Jeremy'ego Benthama, a następnie przekształcony w panoptyczny wzorzec kontroli i nadzoru. Wzorzec ów pozwala zanalizować to, jakie w badanej rzeczywistości są mechanizmy społecznej obserwacji i władzy panoptycznej, a co najważniejsze - jak jednostka dokonuje interioryzacji kontroli, sprawując ją sama nad sobą. Podobnie nie skorzystano z Foucaultowskiej koncepcji władzy pastoralnej, nie zawsze też ukazano dostatecznie szeroko konstelacje wiedzy-władzy. Autorka posługuje się pojęciem medykalizacji, biopolityki, biowładzy, ale nie uwzględnia konstruowanej według podobnych założeń higienizacji - widocznej chociażby w odniesieniu do wychowania młodzieży. Analizując mechanizmy władzy w oparciu o koncepcje Foucaulta, nie pisze o teoretycznym wymiarze opisywanych przez francuskiego uczonego strategii oporu wobec władzy - choć pisze o przejawach owego oporu. Odnosząc się do koncepcji władzy („zarządzania” czy „urządzania”) Foucaulta, w analizie konkretnych przypadków Autorka nie wykorzystała jej do zbadania ogólnych założeń i przejawów systemu normalizacji i mechanizmów kontroli (z całym zbiorem subtelności władzy, która przecież z jednej strony jest dyscyplinująca, z drugiej - łagodna, indywidualizująca, dobroczynna, ma wymiar pozytywny i produktywny) w amerykańskich działaniach humanitarnych. Warto byłoby także uwzględnić spojrzenie Gillesa Deleuze'a na „społeczeństwa dyscyplinarne” i „społeczeństwa kontroli” (Deleuze 2007). Interesujące spostrzeżenia Autorki na temat obecnej w narracjach Amerykanów konstrukcji „zapóźnionej cywilizacyjnie” Polski zyskałyby dzięki wykorzystaniu teorii studiów post-kolonialnych. Opisując postawy Amerykanów wobec społeczeństwa II Rzeczypospolitej, a szczególnie binarne opozycje ich narracji w przedstawianiu warunków egzystencji i działań filantropijnych na rzecz ludzi ze środowisk ubogich i zaniedbanych, warto byłoby wykorzystać choćby uwagi o zasadach rządzących „kolonialnym słownikiem” Frantza Fanona (Fanon 1985).

Interesujące rozważania Autorki o działaniach amerykańskich organizacji humanitarnych na rzecz poprawy psychofizycznej i moralnej kondycji młodzieży warto byłoby pogłębić, uwzględniając współczesne opracowania dotyczące młodzieży. W pracy zwrócono uwagę na znaczenie tekstów Stanleya G. Halla w konceptualizacji adolescencji i powszechne przyjęcie jego teorii dojrzewania oraz modelu podejścia do młodzieży opartego na kontroli i regulacji. Warto byłoby uwzględnić również inne historyczne i współczesne teorie i podejścia poznawcze. Szkoda, że Autorka nie skorzystała ze znakomitych prac Heleny Ostrowickiej, która zaproponowała interesującą koncepcję dominujących we współczesnej nauce profili epistemicznych oraz dokonała analizy dyskursów o młodzieży z uwzględnieniem recepcji idei Michela Foucaulta, w tym kategorii urządzania, dyspozytywu oraz dyskursu edukacyjnego (Ostrowicka 2015a, b). Oczywiście rozprawa S. Kuźmy-Markowskiej nie jest pracą pedagogiczną, ale wykorzystanie dorobku nauk o wychowaniu w rozważaniach o rodzinie, dziecku i dzieciństwie, młodzieży i dorastaniu z pewnością pomogłoby w pogłębieniu refleksji badawczej. Dotyczy to także stosowanych w pracy pojęć - i tak np. wielopłaszczyznowy wymiar rodzicielstwa 
adopcyjnego w omawianej pracy opisano z wykorzystaniem dwóch terminów - adopcji sentymentalnej jako przeciwieństwa adopcji komercyjnej. Wydaje się, że nieobecność opracowań z zakresu pedagogiki czy nauk o rodzinie (choć te ostatnie są wyodrębnione w polskiej klasyfikacji dziedzin i dyscyplin naukowych w obszarze nauk humanistycznych) jest świadomym wyborem i przyjęciem innego podejścia poznawczego. Autorka deklaruje oparcie się na pracach historyków i socjologów badających rodzinę; i tu jednak nie jest konsekwentna, nie sięgając np. do opracowania Tomasza Szlendaka (Szlendak 2012). Oczywiście przedmiot badań wymaga przeprowadzenia wszechstronnej kwerendy w obszarze opracowań anglojęzycznych, ich szerokie wykorzystanie jest zaletą pracy, ale w odniesieniu do niektórych szczegółowych zagadnień, podejmowanych w pracy zdziwienie budzi pomijanie polskich opracowań. Tak jest np. w przypomnieniu działalności Heleny Radlińskiej, nota bene dość lakonicznym. W podrozdziale poświęconym profesjonalistkom - pielęgniarkom i pracownicom społecznym Autorka wspomina o kształceniu pracownic społecznych w założonym przez Radlińską Studium Pracy Społeczno-Oświatowej w Wolnej Wszechnicy Polskiej (nie wspomina o kształceniu tam także mężczyzn). Pisze przy tym, że Radlińska „wypracowała nowatorską i szeroką koncepcję pracy społecznej, kładącą nacisk m.in. na praktyczne przygotowanie do zawodu" (s. 292), powołując się na jeden anglojęzyczny artykuł. Wydaje się, że uzasadnione byłoby nieco szersze przypomnienie roli Radlińskiej i kierowanego przez nią Studium, również w oparciu o bogate polskie piśmiennictwo. Jest to tym istotniejsze, że pisząc o transnarodowym wymiarze ideałów, norm i standardów, warto pamiętać o intensywnej współpracy Radlińskiej z działaczami społeczno-oświatowymi i uczonymi z całej Europy (Theiss 2017; Bołdyrew 2018: 147-149). Zachowane materiały archiwalne świadczą o tym, że choć znacznie rzadziej, to utrzymywała kontakty zawodowe także z Amerykanami (Biblioteka Uniwersytetu Łódzkiego, Sekcja Rękopisów, Archiwum...).

Narracja Autorki jest wyważona i poparta solidnymi argumentami. Bardzo rzadko, ale zdarzają się jednak stwierdzenia, które wydają się nie w pełni uzasadnione. I tak na przykład, pisząc o udziale elitarnych grup społecznych na ziemiach polskich w czasie I wojny światowej i w pierwszych latach II Rzeczypospolitej w organizacji działań dobroczynnych, Autorka podkreśla odmienność sytuacji w Łodzi. Przytacza skargi pracowników łódzkiego Komitetu Tanich Kuchen kierowane do organizacji amerykańskich, dotyczące braku zaangażowania zamożniejszych Łodzian w akcje pomocowe na rzecz dzieci, konkludując, że „małe zaangażowanie elit $\mathrm{w}$ pomoc dzieciom wydaje się być (...) specyfiką relacji społecznych w Łodzi” (s. 163). Warto byłoby sięgnąć do licznych opracowań (z zakresu historii społecznej, historii medycyny oraz historii wychowania), dotyczących działań dobroczynnych i samorządowych na rzecz dzieci i młodzieży w „polskim Manchesterze”, by określić, czy rzeczywiście można mówić o „specyfice relacji społecznych" w Łodzi, czy raczej o przejawie stereotypowego wyobrażenia na temat tego miasta. 
Moje uwagi i sugestie nie podważają wysokiej oceny rozprawy Sylwii Kuźmy-Markowskiej. Zainteresuje ona z pewnością przedstawicieli nauk humanistycznych i społecznych, poszerzając wiedzę o transnarodowym transferze wiedzy, ideałów, norm dotyczących rodziny i wychowania młodego pokolenia, relacji między organizatorami działań pomocowych a ich beneficjentami. Napisana jest precyzyjnym i bogatym pojęciowo językiem (choć nie zawsze uwzględnia specjalistyczną terminologię z zakresu nauk społecznych). Autorka przeprowadziła rozległą kwerendę, zebrała i przedstawiała obfity, niebędący dotychczas w obiegu naukowym materiał źródłowy. Wykorzystała bogaty zasób literatury, głównie autorstwa amerykańskich uczonych. Na kanwie lektury tej interesującej i inspirującej pracy warto jednak przypomnieć o potrzebie proporcjonalnego posiłkowania się opracowaniami polskich specjalistów, jak choćby przywoływanej już Heleny Ostrowickiej, wybitnej badaczki o międzynarodowej renomie z Uniwersytetu Kazimierza Wielkiego w Bydgoszczy. Przypominają się w tym miejscu słowa Ewy Domańskiej postulującej troskę o zachowanie sprawiedliwości epistemicznej w humanistyce. W kontekście rozważań na temat relacji wiedzy/władzy w świecie nauki, geopolityki wiedzy oraz niesprawiedliwości epistemicznej (według cytowanej w artykule Mirandy Fricker występującej $\mathrm{w}$ postaci niesprawiedliwości świadczenia i niesprawiedliwości hermeneutycznej) Domańska zaznacza: „z jednej strony dla tzw. ośrodków tworzenia wiedzy, które mieszczą się w Europie Zachodniej i w Stanach Zjednoczonych, jesteśmy prowincją, która co najwyżej dostarcza ciekawych case studies dla testowania tworzonych tam teorii, z drugiej zaś tak samo traktujemy własne «prowincje» czy/i «peryferie». Proponuję zatem podwójnq dekolonizację: zewnętrzną - dekolonizację Polski jako intelektualnej peryferii wobec centrów tworzenia wiedzy; oraz wewnętrzną - dekolonizację małych ośrodków naukowych, muzealnych, kulturalnych jako peryferyjnych wobec akademickich ośrodków flagowych, takich jak Warszawa i Kraków" (Domańska 2017: 46).

\section{Bibliografia}

Biblioteka Uniwersytetu Łódzkiego, Sekcja Rękopisów, Archiwum Heleny Radlińskiej (zbiór w opracowywaniu).

Bołdyrew A. (2018) Warunki i strategie działalności naukowej polskich akademiczek na niwie pedagogiki i psychologii w latach 1918-1939, „Kwartalnik Pedagogiczny”, nr 4, s. 140-151.

Deleuze G. (2007) Postscriptum o społeczeństwach kontroli w: tenże, Negocjacje 1972-1990, tłum. M. Herer, Wrocław, Wydawnictwo Naukowe Dolnośląskiej Szkoły Wyższej Edukacji TWP.

Domańska E. (2017) Sprawiedliwość epistemiczna w humanistyce zaangażowanej, „Teksty Drugie”, nr 1, s. 41-59. 
Fanon F. (1985) Wyklęty lud ziemi, tłum. H. Tygielska, Warszawa, Państwowy Instytut Wydawniczy.

Kuźma-Markowska S. (2018) Dziecko, rodzina i płeć w amerykańskich inicjatywach humanitarnych i filantropijnych w II Rzeczypospolitej, Warszawa, Wydawnictwo Uniwersytetu Warszawskiego.

Ostrowicka H. (2015a) Przemyśleć z Michelem Foucaultem edukacyjne dyskursy o młodzieży. Dyspozytyw i urządzanie, Kraków, Oficyna Wydawnicza „Impuls”.

Ostrowicka H. (2015b) Urzq̨dzanie młodzieży. Studium analityczno-krytyczne, Kraków, Oficyna Wydawnicza „Impuls”.

Pomorski J. (2017) Polityzacja/mitologizacja historii, czyli w czym neuronauka (i metodologia) może pomóc badaczowi historii najnowszej?, „Historia@Teoria”, nr 4, s. $15-42$.

Szlendak T. (2012) Socjologia rodziny. Ewolucja, historia, zróżnicowanie, Warszawa, Wydawnictwo Naukowe PWN.

Theiss W. (2017) Udział Heleny Radlińskiej w europejskim ruchu społeczno-pedagogicznym (1918-1939), „Society Register”, nr 1, s. 153-166. 